\title{
The Evolution of Personalised Learning - from Different, to Differentiated and Now to Universally Designed
}

\author{
Sarah Humphreys ${ }^{1}$ and Bree Jimenez ${ }^{2 *}$ \\ ${ }^{1}$ Co-Founder Inclusive Schools Australia, Australia \\ ${ }^{2}$ University of Sydney \& Mater Dei School, Camden, Australia
}

Submission: December 03, 2018; Published: December 11, 2018

*Corresponding author: Bree Jimenez, Honorary Research Associate University of Sydney, Sydney, Australia

\section{Introduction}

The rights of students with disability to access and progress through the same curriculum as their peers is supported by legislation across the globe, such as the Disability Standards for Education 2005 in Australia; the Individuals with Disabilities Education Improvement Act 2004 in the United States; the Equality Act 2010 in the United Kingdom. There is a global commitment to promoting equity and excellence in education to ensure that all students will become successful learners, confident and creative individuals and active and informed citizens.

How each country, and even states within a country, pursue achieving this varies; however, as described by Trela \& Jimenez [1] there has been a common shift from providing an education that is 'different' towards providing an education that is 'differentiated'. The focus for educating students with disability has moved away from 'whether or not' they will be educated to 'how' they will learn and progress. This requires an evolution not only in curriculum development but also in educational mindset and practice [2]. In Australia, the development of a national curriculum and its implementation throughout this decade exemplifies a continuing evolution of personalised learning and a shift towards 'universal design'.

\section{Universal Design for Learning}

Universal Design for Learning [3] can play a vital role in disrupting 'business as usual' around education of all students, including those with disability. Although educational research continues to show both increasingly improved social and academic outcomes for students with disabilities, current research rarely focuses on a framework to drive how schools and staff develop and implement instructional practices to teach core academic content to students with more extensive support needs [4]. UDL holds promise for increasing effective inclusive opportunities for all students, with its focus on the curriculum, instruction, and materials as potential barriers, rather than individual student needs as the cause of educational problems [5].
UDL "reduces barriers in instruction, provides appropriate accommodations, supports, and challenges, and maintains high achievement expectations for all students, including students with disabilities and students who are limited English proficient" [6]. The framework of 'curriculum' must be developed and then, sent forward to educators, as something that includes 'instruction and materials'; therefore, supporting flexibility in design of instruction and assessment. Additionally, the embedded nature of UDL allows educators to develop learning environments in which 'accommodations/modification/adjustments' are not seen as "added-on" work for the educator, rather part of an inclusive structure that exists from creation (Jimenez \& Hudson, in press).

\section{Differentiation verses Universally Designed Curricu- lum}

Differentiated still implies that what will be delivered to 'most' will need to be adapted or changed to fit for 'a few'. Curriculum authorities nationally and internationally have struggled to successfully include students with the most significant disabilities as part of a single curriculum. For example, the Australian Curriculum, Assessment and Reporting Authority [7] set out to develop one curriculum inclusive of all learners through a contemporary, flexible three-dimensional design. Curriculum writers drew from the principles of the Universal Design for Learning framework [3] to ensure the curriculum is inclusive of all learners and values diversity by providing for multiple means of representation, action, expression and engagement [8]. It is the relationship between these three dimensions that provides the flexibility for schools and teachers to cater for student diversity through personalised learning [9]. A flexibly designed curriculum gives teachers the control of what will be taught, to what depth, at what pace and in what order based on the needs of their students. However, teachers also require the expertise, confidence and support in knowing how to do that.

To use the Australian Curriculum, as it was intended for students with disability, requires an educational mindset that 
learner variability is the norm, rather than the exception. Universally designing a teaching, learning or assessment experience from the outset is a proactive way to personalise learning and reflects the educational evolution away from different and differentiation. Yet research undertaken by Basham et al. [2] indicates that personalised learning is neither consistently understood nor implemented. This would appear to be the same in Australia where at least three of the eight Australian states and territories have chosen to develop additional content for students with disabilities (Life Skills outcomes and content in New South Wales; Progressing to Foundation levels in Victoria and Western Australia) to guide teachers in their instruction of students with disability and therefore perpetuating something 'different'.

A flexible, multi-dimensional curriculum for all represents a paradigm shift and understanding how to use it to personalise learning and have maximum impact for every learner cannot be left to chance. The research exists to show that access to the regular curriculum for students with disability not only raises teacher expectations but also better prepares students for their adult life [10]. Time and resources need to be invested in supporting teachers to adopt a universal approach to designing and delivering teaching, learning and assessment experiences. This requires teachers to be intentional rather than retrospective in terms of how they plan for diversity, make the learning personally relevant and determine the instructional practices they will need to use.

A framework of UDL is a deliberate and calculated systematic approach to instructional goals, materials, and assessments. The framework is built on an understanding that "barriers to learning are not inherent in the capacities of learners, but instead arise in learners' interactions with inflexible educational goals, materials, methods, and assessments" [6]. The UDL framework provides an all-inclusive philosophical structure within which a state, school system, or school can realize other professional development, policies, and initiatives rather than a series of disconnected

This work is licensed under Creative Commons Attribution 4.0 License DOI: 10.19080/GJIDD.2018.05.555666 adoptions (Jimenez \& Hudson, in press). As argued by Trela \& Jimenez [1], the focus is now on the 'how' students with disability learn and progress through the regular curriculum and the importance of changing our language to reflect the changes in our practice. It is time for 'Universal Design' to replace, or at the very least reduce, the need for 'differentiation' and totally negate the need for 'different'.

\section{References}

1. Trela K, Jimenez B (2013) From Different to Differentiated: Using "Ecological Framework" to Support Personally Relevant Access to General Curriculum for Students with Significant Intellectual Disabilities. Research \& Practice for Persons with Severe Disabilities. 38(2): 117-119.

2. Basham JD, Hall TE, Carter RA (2016) An Operationalised Understanding of Personalized Learning. Journal of Special Education Technology 31(3): 126-136.

3. CAST (2015) How has UDL been defined?

4. Copeland SR, Cosbey J (2008-2009) Making progress in the general curriculum: Rethinking effective instructional practices. Research and Practice for Persons with Severe Disabilities 34(1): 214-227.

5. Jimenez B, Hudson M (in press for 2018). Including students with severe disabilities in general education and the potential of universal design for learning for all children. In: Schuelka M, Johnstone C, Thomas G, Artiles A (Edtns.). SAGE Handbook of inclusion and diversity in education. SAGE, Los Angeles, California, USA.

6. Rose DH, Meyer A, Strangeman N, Rappolt G (2002). Teaching every student in the digital age: Universal Design for Learning. ASCD.

7. (2012) Australian Curriculum, Assessment and Reporting Authority. The Shape of the Australian Curriculum.

8. (2012) Australian Curriculum, Assessment and Reporting Authority. The Shape of the Australian Curriculum: Health and Physical Education.

9. (2018) Australian Curriculum, Assessment and Reporting Authority. Student Diversity Advice Materials.

10. Browder DM, Spooner F (2011) Teaching students with moderate and severe disabilities. Guilford: New York, USA.

\begin{tabular}{l} 
Your next submission with Juniper Publishers \\
will reach you the below assets \\
- Quality Editorial service \\
- Swift Peer Review \\
- Reprints availability \\
- E-prints Service \\
- Manuscript Podcast for convenient understanding \\
- Global attainment for your research \\
- Manuscript accessibility in different formats \\
( Pdf, E-pub, Full Text, Audio) \\
- Unceasing customer service \\
Track the below URL for one-step submission \\
https://juniperpublishers.com/online-submission.php \\
\hline
\end{tabular}

